\title{
PEMBENTUKAN HARGA CABAI MERAH KERITING (Capsicum annum L) DENGAN ANALISIS HARGA KOMODITAS DI SENTRA PRODUKSI DAN PASAR INDUK (Suatu Kasus pada Sentra produksi Cabai Merah Keriting di Kecamatan Cikajang, Pasar Induk Gedebage, Pasar Induk Caringin dan Pasar Induk Kramat Jati)
}

\author{
Oleh \\ DETY SUKMAWATI \\ Universitas Winaya Mukti \\ Mahasiswa Program Doktoral Universitas Padjadjaran \\ Email: detysukmawaty@ymail.com
}

\begin{abstract}
Abstrak
Beberapa indikator empirik yang sering digunakan dalam pengkajian efisiensi pemasaran di antaranya adalah margin pemasaran dan transmisi harga dari pasar konsumen kepada petani atau ke pasar produsen. Adapun transmisi harga yang rendah mencerminkan inefisiensi pemasaran karena hal itu menunjukkan bahwa perubahan harga yang terjadi di tingkat konsumen tidak seluruhnya diteruskan kepada petani, dengan kata lain transmisi harga berlangsung secara tidak sempurna. Pola transmisi harga seperti ini biasanya terjadi jika pedagang memiliki kekuatan monopsoni sehingga mereka dapat mengendalikan harga beli dari petani. Penelitian ini bertujuan untuk mengetahui Pembentukan harga cabai merah keriting dengan analisis harga komoditas, data yang digunakan adalah data time series harian harga cabai merah keriting selama setahun pada tahun 2014 yang bersumber dari Dinas Pertanian Tanaman Pangan Jawa Barat dan analisis menggunakan program Eviews 8. Hasil analisis menunjukkan bahwa pembentukan harga cabai merah keriting bisa dilakukan dengan analisis harga komoditas pertanian hal ini bisa menunjukkan sebagai indikator kesehatan pasar. Hasil analisis menunjukkan nilai koefisien korelasi tertinggi berada antara PI Caringin dan PI Gedebage persentase perubahannya $99 \%$, artinya perubahan harga yang terjadi di PI Caringin di transmisikan secara sempurna ke PI Gedebage. Pembentukan harga dapat dilihat juga dengan analisis integrasi pasar, analisis ini bertujuan untuk mengetahui pasar mana yang dominan dalam pembentukan harga cabai merah keriting. Hasil analisis menunjukkan kenaikan harga cabai merah keriting 1 rupiah di sentra produksi Cikajang akan menaikkan harga cabai merah keriting sebesar 0.77 rupiah (perubahan $77 \%$ ) di PI Kramat Jati, hal ini menunjukkan bahwa PI Kramat jati dominan pembentuk harga cabai merah keriting.
\end{abstract}

Kata kunci: pembentukan harga, sentra produksi, pasar induk

\section{PENDAHULUAN}

Komoditas cabai merah di provinsi Jawa Barat secara nasional merupakan salah satu komoditas unggulan. Pada tahun 2007 produktivitas cabai di garut diatas rata-rata produktivitas di Jawa Barat (Adang agustian dan Iwan Setiajie A, 2008). Luas tanam per Tahun cabai merah di Sentra produksi sayuran kabupaten Garut ( 3.038 ha) merupakan luas tanam terluas dari sentra produksi sayuran cabai merah di Jawa Barat yaitu Bandung, Cianjur, Majalengka dan Tasikmalaya (Dinas Pertanian Tanaman Pangan Provinsi Jawa Barat, 2013).

Seperti halnya komoditas hortikultura pada umumnya, peranan pemasaran pada komoditas cabai merah memberikan kontribusi penting dalam peningkatan kinerja usahatani komoditas cabai merah secara keseluruhan mengingat sifat unik komoditas hortikultura secara umum seperti mudah busuk, mudah rusak, volumenious, produksinya bersifat musiman sementara konsumsi terjadi sepanjang tahun. Secara empiris dilapangan seringkali dijumpai bahwa para petani produsen tampaknya tetap saja menghadapi fluktuasi harga terutama saat panen, dan para pedaganglah yang dapat lebih akses untuk dapat memperoleh harga yang lebih tinggi, oleh karena itu, peningkatan produksi komoditas pertanian termasuk cabai merah perlu diiringi dengan perbaikan pada sistem pemasarannya, sehingga pihak petani sebagai produsen komoditas ini diharapkan dapat memperoleh bagian harga yang memadai bagi peningkatan usahataninnya (Adang agustian dan Iwa Setiajie A, 2008).

Secara umum sistem pemasaran komoditas pertanian termasuk hortikultura masih menjadi bagian yang lemah dari aliran komoditas . Masih lemahnya pemasaran komoditas pertanian tersebut karena belum berjalan secara 


\section{MIMBAR \\ A GRIBISNIS}

ISSN 2460-4321

Volume 1・Nomor 1・Juli 2015

efisien. Suatu sistem pemasaran yang efisien harus mampu memenuhi dua persyaratan yaitu (1) mengumpulkan hasil pertanian dari produsen ke konsumen dengan biaya serendahrendahnya, (2) mampu mendistribusikan pembagian balas jasa yang adil dari keseluruhan harga konsumen akhir kepada semua pihak yang terlibat mulai dari kegiatan produksi hingga pemasaran (Mubyarto, 1989).

Pada umumnya besarnya marjin pemasaran merupakan indikator yang paling sering digunakan untuk mendeteksi terjadinya inefisiensi pemasaran yang disebabkan oleh kekuatan pasar yang tidak sempurna. Namun perlu digarisbawahi bahwa marjin pemasaran yang tinggi tidak selalu mencerminkan adanya kekuatan monopsoni yang secara teoritis ditunjukkan oleh adanya keuntungan pedagangyang berlebihan (non zero profit).

Beberapa indikator empirik yang sering digunakan dalam pengkajian efisiensi pemasaran di antaranya adalah margin pemasaran dan transmisi harga dari pasar konsumen kepada petani atau ke pasar produsen. Sistem pemasaran semakin efisien apabila besarnya marjin pemasaran yang merupakan jumlah dari biaya pemasaran dan keuntungan pedagang semakin kecil. Dengan kata lain, perbedaan antara harga yang diterima petani dan harga yang dibayar konsumen semakin kecil. Adapun transmisi harga yang rendah mencerminkan inefisiensi pemasaran karena hal itu menunjukkan bahwa perubahan harga yang terjadi di tingkat konsumen tidak seluruhnya diteruskan kepada petani, dengan kata lain transmisi harga berlangsung secara tidak sempurna. Pola transmisi harga seperti ini biasanya terjadi jika pedagang memiliki kekuatan monopsoni sehingga mereka dapat mengendalikan harga beli dari petani.

Pada pasar persaingan sempurna selisih antara harga yang dibayar konsumen dan harga yang diterima petani lebih rendah dibanding pada kondisi pasar monopsoni, dengan kata lain, marjin pemasaran akan semakin besar jika terdapat kekuatan monopsoni. Pada kondisi pasar monopsoni transmisi harga dari pasar konsumen kepada petani juga berlangsung secara tidak sempurna. Pola transmisi harga seperti ini menyebabkan korelasi harga di tingkat konsumen dan di tingkat petani akan semakin rendah dan fluktuasi harga di pasar produsen akan lebih rendah daripada di pasar konsumen. Fluktuasi harga yang tinggi merupakan salah satu isu sentral yang sering muncul dalam pemasaran komoditas hortikultura (Bambang Irawan 2007).

Dalam kurun 10 tahun perkembangan harga di 4 tempat mengalami fluktuasi dengan rentang yang sangat berbeda, harga di sentra produksi lebih rendah dari ketiga Pasar Induk dan harga di Pasar Induk Gede Bage berbeda dengan Pasar Induk Caringin, walaupun kedua tempat tersebut terdapat pada kota yang sama dan harga di pasar induk kramat jati melebihi pasar induk caringin hanya tahun 2005 harga di pasar induk gede bage dibawah harga sentra produksi cikajang hal ini bisa terjadi jumlah pasokan di pasar induk gede bage banyak artinya komoditas yang masuk pada pasar tersebut berasal dari lebih satu pemasok. Hal ini mengidikasikan bahwa harga tidak stabil selama 10 tahun di ketiga tempat, apakah harga tidak stabil, mekanisme pasar tidak bekerja, distribusi hasil antar pelaku pasar tidak adil, hal menunjukkan pasar tidak sehat.

Pasar tidak sehat, terdapat dua hal yaitu (1) harga terlalu murah, merugikan produsen, (2) harga terlalu mahal, merugikan konsumen .ketidakstabilan harga tersebut dapat dilihat dalam perkembangan harga per bulan di ketida tempat pada tahun terakhir (2012), seperti terlihat pada Gambar 4.

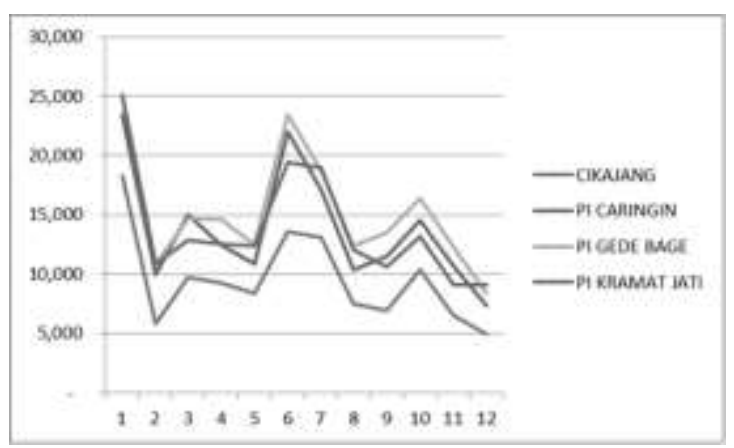

Sumber : Dinas Pertanian Tanaman Pangan Provinsi Jawa Barat 2013 (Diolah).

\section{Gambar 4. Perkembangan Harga Cabai Merah Keriting di Cikajang, Pasar Induk Caringin, Pasar Induk Gede Bage, dan Pasar Induk Kramat Jati per Bulan Tahun 2012}

Terlihat bahwa harga cabai merah keriting sangat berfluktuasi. Antara harga di sentra produksi dan pasar, antara pasar pada kota 
yang sama dan antar kota mengalami perubahan setiap bulannya dan harga di sentra produksi jauh dibawah ketiga pasar induk. Pada kondisi seperti ini apakah perubahan harga komoditas di pasar merubah harga yang diterima petani di sentra produksi.

Harga produk pertanian tergolong sangat fluktuatif dengan rentang tingkat harga yang sangat lebar, apalagi setelah dikaitkan dengan future trading. Pada waktu tertentu, seperti musim panen dan musim hujan harganya bisa sangat rendah namun pada saat yang lain bisa sangat tinggi. Harga yang sangat fluktuatif secara teoritis akan menyulitkan prediksi bisnis, baik dalam perhitungan rugi laba maupun manajemen resiko. Harga yang demikian seringkali hanya menguntungkan para spekulan yang umumnya para pedagang tertentu yang mampu mengelola stok secara baik dan cermat. Pengendalian fluktuasi ini merupakan tantangan tersendiri khususnya dalam perumusan kebijakan yang tepat terutama menyangkut kebijakan proteksi pasar domestik dan perlindungan harga di tingkat petani (Mohamad Ismet.2009). Untuk itu perlu diketahui bagaimana disparitas harga cabai merah keriting yang terjadi di sentra produksi dengan Pasar Induk melalui transmisi harga dan integrasi pasar dapat diketahui pasar mana yang paling dominan dalam pembentukan harga.

\section{METODE PENELITIAN}

Berdasar sifat dan masalahnya rancangan penelitian ini termasuk katagori Penelitian Korelasional yaitu untuk digunakan untuk mengetahui Transmisi harga dan Integrasi Pasar. Tujuan penelitian ini untuk mendeteksi sejauhmana variasi-variasi pada suatu faktor berkaitan dengan variasi-variasi pada satu atau lebih faktor lain berdasarkan pada koefisien korelasi. Penelitian ini menggunakan data time series harga cabai merah pada sentra produksi cabai merah keriting cikajang Kabupaten Garut, Pasar Induk Caringin , Pasar Induk Gedebage dan Pasar Induk kramat Jati, dengan menggunakan data harga cabai merah keriting harian pada tahun 2014 . Data yang digunakan bersumber dari Dinas Pertanian Tanaman Pangan Jawa Barat dan dianalisis dengan menggunakan program EVIEWS 8.

\section{HASIL DAN PEMBAHASAN}

Pembentukan harga cabai merah keriting bisa dilakukan dengan analisis harga komoditas pertanian hal ini bisa menunjukkan sebagai indikator kesehatan pasar. Indikator kesehatan pasar dicirikan dengan apakah harga terlalu mahal, harga terlalu murah, harga tidak stabil, bekerjanya mekanisme pasar,struktur pasar cenderung monopoli dan bisa meramalkan harga. Pasar tidak sehat dicirikan dengan harga tidak stabil, mekanisme pasar tidak bekerja dan distribusi hasil antar pelaku pasar tidak adil. Analisis harga komoditas yang digunakan bisa dengan Analisis trasmisi Harga ,Analisis Integrasi Pasar dan Monopoli Indeks (Jamhari,2013) yang ketiganya mempunyai maksud dan tujuan.

Transmisi harga pada pemasaran komoditas pertanian dari pasar produsen yang relatif rendah merupakan salah satu indikator yang mencerminkan adanya kekuatan monopsoni atau oligopsoni pada pedagang. Hal ini karena pedagang yang memiliki kekuatan monopsoni atau oligopsoni dapat mengendalikan harga beli dari petani sehingga walaupun harga di tingkat konsumen relatif tetap tetapi pedagang tersebut dapat menekan harga beli dari petani untuk memaksimumkan keuntungannya. Begitu pula jika terjadi kenaikan harga di tingkat konsumen, maka pedagang dapat meneruskan kenaikan harga tersebut kepada petani secara tidak sempurna, dengan kata lain kenaikan harga yang diterima petani lebih rendah dibanding kenaikan harga yang dibayar konsumen. Pola transmisi harga seperti ini tidak menguntungkan bagi petani karena kenaikan harga yang terjadi di tingkat konsumen tidak sepenuhnya dapat dinikmati petani, sebaliknya jika terjadi penurunan harga.

Dalam jangka panjang harga komoditas cenderung naik akibat naiknya permintaan konsumen. Namun laju kenaikan harga di tingkat konsumen dapat berbeda dengan laju kenaikan harga di tingkat petani, dan tergantung kepada perilaku pedagang dalam melakukan transmisi harga dari konsumen kepada petani. Pada pasar yang bersaing sempurna pedagang akan meneruskan setiap kenaikan harga di tingkat konsumen dengan besaran yang relatif sama kepada petani, dengan kata lain kenaikan harga di tingkat konsumen relatif sama besar dengan kenaikan harga di tingkat petani. Tetapi 


\section{MIMBAR \\ A GRIBISNIS}

ISSN 2460-4321

Volume 1・ Nomor 1・ Juli 2015

pada pasar dengan kekuatan monopsoni/oligopsoni kenaikan harga di tingkat petani akan lebih kecil dibanding kenaikan harga di tingkat konsumen akibat perilaku pedagang yang berusaha memaksimumkan keuntungannya dengan memberikan informasi harga yang tidak sempurna untuk menekan harga beli dari petani ( Irawan, 2007).

Analisis transmisi harga bermanfaat dalam menggambarkan efisiensi pasar yang berlangsung pada setiap pasar dan sebagai salah satu bentuk peramalan harga pada suatu pasar dengan memanfaatkan informasi harga yang terjadi pada pasar yang menjadi acuannya. Transmisi harga vertikal pada umumnya dilakukan terhadap suatu komoditas pada level yang berbeda dalam rantai pasok. Transmisi harga vertikal mengindikasikan adanya market power yang umumnya dipicu oleh konsentrasi pasar yang lebih tinggi pada suatu level dalam rantai pasok. Sementara itu transmisi harga spasial dilakukan untuk melihat respon perubahan harga yang dipicu oleh perubahan harga komoditas yang sama di wilayah lain, baik antar daerah dalam suatu negara (Goodwin, 2006 dalam Nurmalina, 2011).

Transmisi harga menguji hubungan antara series harga pada channel yang berbeda pada rantai pemasaran ataupun pada pasar yang terpisah. Transmisi harga yang diterapkan pada konsep persaingan harga. Dengan kata lain, transmisi harga terjadi jika shock di pasar yang satu maka akan ditransmisikan ke pasar yang lain atau bagaimana harga domestik melakukan penyesuaian terhadap harga dunia. Transmisi harga terjadi pada pasar yang terintegrasi.

Terdapat dua faktor yang menyebabkan adanya variasi transmisi harga, pertama, adanya kekuatan monopsoni dan oligopsoni pada pedagang sehingga pedagang memiliki kekuatan untuk mengendalikan harga beli dari petani atau harga di tingkat produsen. Adanya kekuatan monopsoni pada pedagang menyebabkan kenaikan harga yang terjadi di tingkat konsumen tidak selalu diteruskan kepada petani secara sempurna. Kedua, rantai pemasaran yang semakin panjang memungkinkan terjadinya akumulasi bias transmisi harga yang semakin besar. Rantai pemasaran yang panjang dapat disebabkan oleh jarak pemasaran yang semakin jauh antara daerah produsen dan konsumen. Jarak pemasaran yang lebih jauh dapat terjadi karena produksi komoditas terkonsentrasi di daerahdaerah tertentu sedangkan daerah konsumennya relatif tersebar dalam lingkup wilayah yang lebih luas (Nurmalina, dkk. 2011 ).

Hasil analisis transmisi harga menunjukkan bahwa koefisien korelasi berkisar sampai +1 artinya keempat tempat tersebut harga cabai merah keriting hubungannya sangat erat artinya kenaikan harga ditempat yang satu akan menaikkan harga di tempat lain, lebih jelasnya hasil analisis pada matrik dibawah ini.

Matriks Koefisien Korelasi Harga Cabai Merah Keriting

\begin{tabular}{|l|r|r|r|r|}
\hline & \multicolumn{1}{|c|}{ CIKAJANG } & PI CARINGIN & \multicolumn{1}{c|}{ PI GEDEBAGE } & \multicolumn{1}{c|}{ PI KRAMAT JATI } \\
\hline CIKAJANG & 1.000000 & 0.982996 & 0.981259 & 0.989718 \\
\hline PI CARINGIN & 0.982996 & 1.000000 & 0.997045 & 0.984766 \\
\hline PI GEDEBAGE & 0.981259 & 0.997045 & 1.000000 & 0.983196 \\
\hline PI KRAMAT JATI & 0.989718 & 0.984766 & 0.983196 & 1.000000 \\
\hline
\end{tabular}

Nilai koefisien korelasi tertinggi berada antara PI Caringin dan PI Gedebage persentase perubahannya $99 \%$, perubahan harga yang terjadi di PI Caringin di transmisikan secara sempurna ke PI Gedebage. Harga tertinggi di PI Gedebage menunjukkan PI Gedebage adalah Dinas Pertanian Tanaman Pangan Jawa Barat pada Pusat Informasi sentra produksi Cikajang sekarang tidak terdapat pasokan cabai merah keriting dari sentra produksi Cikajang ke PI
Gedebage, hal ini menunjukkan aliran komoditas cabai merah keriting dari pasokan PI Caringin ke PI Gedebage dari PI Gedebage ke Pasar Tradisional sekitarnya.

Pembentukan harga dapat dilihat dengan analisis harga komoditas lainnya dengan analisis integrasi pasar, analisis ini bertujuan untuk mengetahui pasar mana yang dominan dalam pembentukan harga cabai 
Pembentukan Harga Cabai Merah Keriting (Capsicum annum L) dengan Analisis Harga Komoditas di Sentra Produksi dan Pasar Induk (Suatu Kasus pada Sentra produksi Cabai Merah Keriting di Kecamatan Cikajang, Pasar Induk Gedebage, Pasar Induk Caringin dan Pasar Induk Kramat Jati)

\section{DETY SUKMAWATI}

merah keriting, dari hasil analisis menunjukkan persamaan sebagai berikut:

$$
\begin{aligned}
\mathrm{A}= & 2681.871495+0.7723454846 * \mathrm{X}+ \\
& 0.2696970479 * \mathrm{Y}+0.1070285489 * \mathrm{Z}
\end{aligned}
$$

$\mathrm{A}=$ PI Kramat jati

$\mathrm{X}=$ Cikajang

$\mathrm{Y}=\mathrm{PI}$ Caringin

$\mathrm{Z}=\mathrm{PI}$ Gedebage

Pada persamaan tersebut terlihat bahwa setiap kenaikan harga cabai merah keriting 1 rupiah di sentra produksi Cikajang akan menaikkan harga cabai merah keriting sebesar 0.77 rupiah (perubahan $77 \%$ ) di PI Kramat Jati, hal ini menunjukkan bahwa PI Kramat jati dominan pembentuk harga cabai merah keriting. Harga cabai merah keriting di sentra produksi Cikajang ditentukan atau dipengaruhi secara langsung dari harga cabai merah keriting di PI Kramat jati, dan pembentuk harga cabai merah keriting di PI Kramat jati berdasar pasokan yang masuk ke PI kramat jati yang berasal dari seluruh daerah seperti Jawa Tengah, sumatra. dan terutama pasokan cabai merah keriting dari 5 sentra produksi cabai merah keriting di Jawa Barat yaitu Lembang, Pangalengan, Cipanas, Ciwidey, STA Ciamis.

\section{PENUTUP}

Pembentukan harga cabai merah keriting bisa dilakukan dengan analisis harga komoditas pertanian hal ini bisa menunjukkan sebagai indikator kesehatan pasar. Hasil analisis menunjukkan nilai koefisien korelasi tertinggi berada antara PI Caringin dan PI Gedebage persentase perubahannya $99 \%$, artinya perubahan harga yang terjadi di PI Caringin di transmisikan dengan cepat ke PI Gedebage. Pembentukan harga dapat dilihat juga dengan analisis integrasi pasar, analisis ini bertujuan untuk mengetahui pasar mana yang dominan dalam pembentukan harga cabai merah keriting. Hasil analisis menunjukkan kenaikan harga cabai merah keriting 1 rupiah di sentra produksi Cikajang akan menaikkan harga cabai merah keriting sebesar 0.77 rupiah (perubahan $77 \%$ ) di PI Kramat Jati, hal ini menunjukkan bahwa PI Kramat jati dominan pembentuk harga cabai merah keriting.

\section{DAFTAR PUSTAKA}

Adang Agustian dan Iwan Setiajie A. 2008. Analisis Perkembangan Harga dan Rantai Pemasaran Komoditas Cabai Merah di Provinsi Jawa Barat Seminar Nasional Dinamika Pembangunan Pertanian dan Perdesaan. Pusat Analisis Sosial Ekonomi dan kebijakan Pertanian Departemen Pertanian. Bogor.

Bambang Irawan . 2007. Fluktuasi Harga , Transmisi Harga dan Marjin Pemasaran Sayuran dan Buah. Analisis kebijakan Pertanian vol 5 no 4 : 358-373. Pusat Analisis Sosial Ekonomi dan Kebijakan Pertanian, Bogor.

Dinas Pertanian Tanaman Pangan provinsi Jawa Barat. 2013. Sentra Produksi Sayuran.Data Dinas Pertanian Tanaman Pangan Provinsi Jawa Barat.

Mubyarto.1989. Pengantar Ekonomi Pertanian. LP3ES, Jakarta.

Mohamad Ismet.2009. Strategi dan Kebijakan Pemasaran Produk Agribinis dalam Bunga Rampai Agribinis Seri pemasaran. Departemen Agribisnis Fakultas Ekonomi dan Manajemen IPB. Bogor

Rita Nurmalina, Harmini, dan Nia Rosiana.2011. Transmisi Harga guka Tebu.Prosiding Seminar Penelitian Unggulan Departemen Agribisnis:369-394 .Departemen Agribisnis Fakultas Ekonomi dan Manajemen IPB, Bogor. 


\section{MIMBAR Agribisnis ISSN 2460-432I \\ Volume 1・Nomor 1 • Juli 2015}

